\title{
DETERMINATION OF THE STRUCTURE OF TASKS FOR PHOSPHORIC ORE SMELTING FURNACE CONTROL
}

\author{
Akhmet Ibraev, Perdesh Khairullina \\ K.I. Satpayev Kazakh National Technical University. Institute of Information and Communication Technologies
}

Abstract. The article is devoted to definition of the structure of problems of a control system by the ore-smelting furnace for melting of phosphoric raw materials. The solution of this task is offered to be carried out on the basis of decomposition methods with use of mathematical models of the process.

Keywords: ore-smelting furnaces, electric smelting, control of the ore-smelting furnace, mathematical model

\section{OKREŚLENIE STRUKTURY ZADAŃ STEROWANIA PIECEM DO WYTAPIANIA RUD FOSFORU}

Streszczenie. Artykut poświęcony jest omówieniu struktury zadań systemu sterowania piecem do wytapiania rud fosforu. Zaproponowano rozwiązanie tego zadania w oparciu o metody dekompozycji z wykorzystaniem modelowania matematycznego procesu.

Słowa kluczowe: piece do wytopu rud, wytapianie elektryczne, sterowanie piecem do wytopu rudy, model matematyczny

\section{Introduction}

Ore-smelting furnaces for melting raw materials are widely used in the phosphate industry. Increasingly stringent requirements (including environmental and economic) are currently applied to the effectiveness of functioning and quality of products of these furnaces and that cannot be done without the use of modern management techniques and the creation of systems of automation with the use of modern technological means, especially computers and controllers (SCADA-systems).

Phosphoric ore-smelting furnace (POSF) of an enclosed type is characterized by the limited availability of control of process variables, insufficient level of study, aggressive environment and potential dangers. As an object of control, a phosphoric oresmelting furnace is a complex multi-dimensional dynamic industrial complex, which has a considerable inertia, close interrelationship of input and output variables, significant level of disturbances and limited traceability of a large number of variables [1].

The composition of the vector of process input variables includes such variables as the consumption of phosphorite, electrode paste, phosphorite compositions, quartzite, coke, ashes of reductant; type of raw material used and maximum generating capacity of furnace facility.

The vector of output variables of technological flows of the process includes the following:

1. the variables that can be calculated using a mathematical model of the process: the yield and composition of the slag, dust, ferrophosphorus and a yield of phosphorus; mass and volume yield of the furnace gas, its density, mass and mass change of carbonaceous layer; total specific energy consumption, the content of $\mathrm{P}_{2} \mathrm{O}_{5}$ in slag, power consumption of the furnace facility, electrical efficiency, linear consumption of electrodes;

2. the variables that can be measured: strength of current; position of electrodes; volumetric gas yield; higher harmonics in the electrodes current, the temperature of furnace gas, electric power consumption (according to electric meter), the amount of electricity consumed between electrodes slipping, power consumption during closed slag tap holes according to meter reading.

The vector of control variables include: consumption of coke and quartzite, changing capacity of the furnace by moving the electrodes (for changing current intensity) or switching voltage levels of the furnace transformer (linear voltage at the electrodes), flushing of slug and outflow of ferrophosphorus.

Significant disturbing influences include: random fluctuations of component composition of furnace charge (chemical and granulometric content of furnace charge, ash content and humidity of furnace charge); power surges in the supply network, fistulas, sintering and collapses of furnace charge. As a result of these factors, the amount of reacted carbon in the reaction space of the furnace is changed, which in turn, leads to a vibration of resistance of sub-electrode space defined by the mass of carbon layer [2].

\section{Formulation of the problem}

Existing ore-smelting furnace (for melting phosphoric raw materials) automation systems usually solve the problems of monitoring and control of individual technological variables and process control is based on an intuitive, mainly qualitative perception of the characteristics of furnace condition by service personnel [3]. Predictive mathematical models of the process are not used, and therefore, there is no proper efficiency of operational control. Subjective nature of the process assessment leads to a very approximate, often incorrect determination of control actions, resulting in deviations from nominal progress of the process [5]. Adjustment of quartzite and coke dosages is based on the results of chemical analysis of the composition of slag (after draining it from the furnace). The lack of efficiency in determining the composition of the slag leads to a large time lag between changes in the composition of the melt and the need to adjust the composition of furnace charge. The disadvantages of POSF electrical control system mode of operation include the lack methods and algorithms for informed decision making on the optimal ratio of current and voltage for a given capacity of the furnace. It should be noted the absence of any relationship between the problems being solved, because the variables of control and regulation are selected at the level of local design decisions.

In this regard, there is a need to formalize the selection of control problems structure through the application of mathematical models and modern technical means of automation.

\section{Decomposition of the problem}

Considerable inertia of the process, high level of disturbing influences, failure to ensure operational control of several important process variables determines the complexity of the control problem for ore-smelting furnace. In this regard, the decision of this problem is proposed to carry out based on mathematical models of the process with determining interrelated composition solved on the basis of decomposition methods [4].

The structure of automation system for ore-smelting furnace (for smelting phosphoric raw materials) tasks was determined on the basis of systematic analysis of technological complex as the control object, the nature of occurring physical and chemical processes, dynamic properties of the control channels, their 
relationship with each other and with regard to the nature of mathematical description of the object. The use of a systematic approach to the synthesis of complex automation system structure for ore-smelting classified as "complex" (in system analysis terms) allows to the greatest extent take into account peculiarities of their interrelated management. At the same time possibilities of technical means of control and management were taken into account [6].

Structuring a control system (allocation of tasks and subsystems) was performed on the basis of determining (forming) of control and recording and management objectives for each manufacturing operation, i.e. by building "objectives tree", from general (increasing the efficiency of the smelting process as a whole at the top control level), to particular (control and recording and providing stabilization of selected modes) objectives at lower levels.

Achieving selected objectives of top-level is provided through achieving the objectives of lower levels (provided there is a consistency of these objectives). Definition of the system functioning objectives (and tasks to be solved respectively) at lower levels of control is carried out in accordance with the principles of technological and structural and temporal decomposition for the following backbone properties:

- history of individual operations for loading materials to the furnace, melting them and receiving products;

- slots for solving monitoring and control tasks (current and operational tasks), solving tasks at regular intervals taking into account dynamic characteristics of the control channels.

The depth of decomposition was assigned as a condition for achieving such a degree of detailing the objectives, which allows connecting the implementation of "the lower branches of objectives tree" with the specific tasks of monitoring, recording and control that should be addressed in the system. As a result, on the basis of this "objectives tree" control requirements were determined by the structure of the control system of ore-smelting furnace as a well-ordered set of problems being solved in the system.

Based on this approach, it was determined that the automation system of ore-smelting furnace to be formed as a hierarchical multilevel system. At the top level, the control tasks of technological complex as a whole are solved, which consist in the need of completing shift-day targets for the production of primary products and other melting products. At the lower level, tasks of control and stabilization of designed process conditions are solved.

In accordance with these principles, two groups of interrelated tasks in the general problem of ore-smelting furnace control were identified (Figure 1):

- Control of melting process conditions;

- Control of energy mode.

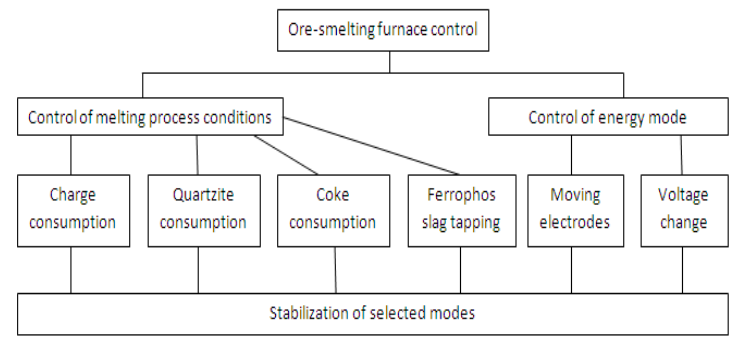

Fig. 1. Structure of phosphoric ore-smelting furnace control tasks

The task of control of melting technological process consists in determining the flow ratio of material flow (consumption of charge, coke, quartzite in the furnace) taking into account their current composition and condition of the furnace (nominal electric capacity of the furnace, the amount and composition of output products - waste gases, slag and ferrophos). The main interval for solving the task - the change, with the clock adjustment, if necessary. Solving the task is carried out on the basis of the static predictive mathematical model based on the equations of the material balance of the process.

Substantial statement of tasks of energy mode control for electric furnace is formulated as follows: to determine the amount of penetration of the electrodes (conductivity below the electrodes) for a given (current) rates of consumption and chemical composition of the charge, minimizing specific energy consumption under restrictions on smelting rate, the loss of phosphorus with the dump slag, the overall capacity of the furnace, the phase voltage.

Energy mode control is carried out by changing voltage level at the transformer and moving the electrodes to maintain a given current load.

The lower level of control structure is represented by tasks of stabilization of selected modes, with the tasks of monitoring process variables.

\section{Conclusion}

Based on the decomposition methods, the structure of tasks for the system of ore-smelting furnace (for smelting of phosphoric raw materials) control was determined. Were formulated meaningful tasks settings for control of technological and energy modes of the smelting process, the solution of which is expected to use mathematical model of the process control channels.

\section{References}

[1] Ibraev A.H., Beisenova P.S.: Certain issues of developing automation system for ore-smelting furnace of phosphorus production. Almaty: Bulletin of the Kazakh National Technical University, 2012, No. 2 (90), pp. 295-297.

[2] Ibraev A.H., Khairullina P.S. About the problem of developing a mathematical model of electric smelting of phosphoric raw material. Novosibirsk: Proceedings of the VII Annual International scientific-practical conference "Prospects of development of information technology," 2012, pp. 158-160.

[3] Ibraev A.H., Khairullina P.S.: Formulation of the problems of phosphoric oresmelting furnace control systems. Almaty: Proceedings of the International Scientific Conference "Information and communication technologies: education, science, practice", II Volume, 2012, pp. 89-91.

[4] Ibraev A.H., Khairullina P.S., Dyusembin E.E.: Creation of mathematical model of process electric smelting of phosphoric raw materials. Almaty: Bulletin of the Kazakh National Technical University, 2013, No. 4, pp. $277-281$.

[5] Standing technological specifications, number 4, Yellow phosphorus production, Shop number 5. VF LLP "Kazphosphate", 2010.

[6] Suleimenov B.A., Terlekpaeva S.D.: Modeling methods of control processes for electrofusion phosphorus ore-smelting furnace. Almaty: Proceedings of the International Scientific Conference "Information and communication technologies: education, science, practice", II Volume, 2012, pp. 164-166.

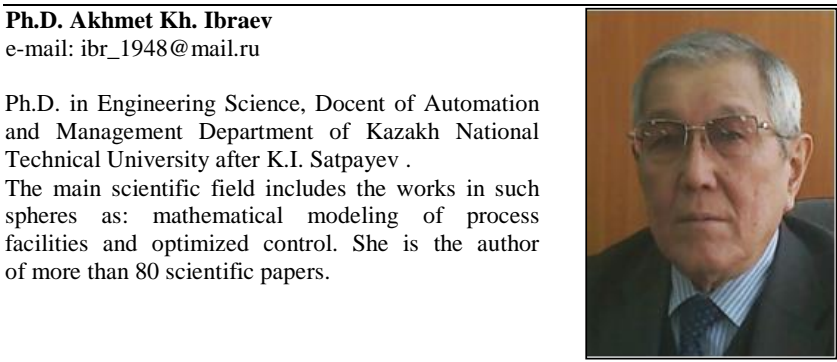

M.Sc. Perdesh Khairullina

Perdesh S. Khairullina conducts research in the field of electric melting of phosphoric raw materials. She has 5 research publications. She is a third-year doctoral student of the Ph.D. doctor's department of Kazakh National Technical University in "Automation and Control". The theme of her work is "The development of an automated control system by process of electric smelting of phosphoric raw materials".

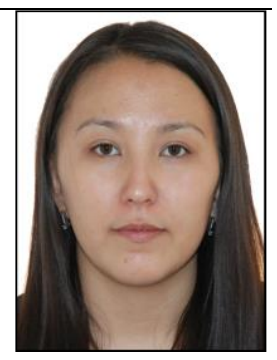

